\title{
EVALUASI PELAPORAN TANGGUNG JAWAB SOSIAL PADA PT BUKIT ASAM (PERSERO) TBK
}

\author{
Rosinta Ria Panggabean \\ Accounting and Finance Department, Faculty of Economics and Communication, BINUS University \\ Jln. KH Syahdan No 9, Palmerah, Jakarta Barat 11480 \\ rosinta_ria_panggabean@yahoo.com
}

\begin{abstract}
This study uses a content analysis framework that provides information on the comprehensiveness of corporate social responsibility (CSR) reporting, an important aspect of social and environmental accountability. Comprehensive reporting requires three types of information for each disclosed CSR item: (i) vision and goals, (ii) management approach, and (iii) performance indicators. This study evaluates the comprehensiveness of CSR reporting using the 2011 annual report of PT Bukit Asam (Persero) Tbk. The content analysis reveals a low level of comprehensive reporting. This finding complements those of prior studies on the completeness of CSR reporting.
\end{abstract}

Keywords: Social accounting, CSR, environmental accounting, PT Bukit Asam (Persero) Tbk

\begin{abstract}
ABSTRAK
Penelitian ini menggunakan sebuah kerangka kerja analisis konten yang menyediakan informasi mengenai kelengkapan pelaporan tanggung jawab sosial perusahaan (CSR) yang merupakan aspek penting dari akuntabilitas sosial dan lingkungan. Pelaporan yang komprehensif memerlukan tiga jenis informasi untuk setiap item CSR yang diungkapkan: (i) visi dan tujuan, (ii) pendekatan manajemen, dan (iii) indikator kinerja. Penelitian ini mengevaluasi kelengkapan pelaporan CSR dengan menggunakan laporan tahunan 2011 PT Bukit Asam (Persero) Tbk. Analisis isi mengungkapkan rendahnya tingkat pelaporan yang komprehensif. Temuan ini melengkapi penelitian sebelumnya mengenai kelengkapan pelaporan CSR.
\end{abstract}

Kata kunci: Akuntansi sosial, CSR, akuntansi lingkungan, PT Bukit Asam (Persero) Tbk. 


\section{PENDAHULUAN}

Praktik pengungkapan sosial dan lingkungan telah diusulkan oleh para ahli akuntansi sosial sebagai mekanisme dimana tugas akuntabilitas dapat dilaksanakan karena praktik ini dapat menginformasikan kepada berbagai jenis pemangku kepentingan mengenai dampak sosial dan lingkungan perusahaan (Unerman, 2000). Namun, untuk melaksanakan akuntabilitas, pengungkapan ini perlu menunjukkan penerimaan perusahaan terhadap tanggung jawab sosial perusahaan dan lingkungan (Adams, 2004). Menurut Adams (2004), penerimaan ini dapat dibuktikan melalui pernyataan nilai-nilai yang jelas yang sesuai dengan tujuan dan sasaran diukur dengan tanggal pencapaian yang diharapkan saat perusahaan harus melaporkan kemajuan mereka.

Meskipun perusahaan semakin banyak mengungkapkan informasi tanggung jawab sosial perusahaan (CSR) (Archel, Fernandez, \& Larrinaga, 2008), sangat dipertanyakan apakah laporan tahunan, laporan CSR yang berdiri sendiri atau laporan sosial dan lingkungan dapat memenuhi peningkatan permintaan untuk akuntabilitas (Milne \& Gray, 2007). Hopwood (2009) menyuarakan kesan bahwa perusahaan melaporkan lebih pada tujuan dan niat dari pada tindakan aktual dan kinerja. Untuk menutup kesenjangan ini, penelitian sebelumnya (van Staden \& Hooks, 2007) menunjukkan bahwa perusahaan harus melaporkan secara komprehensif dengan memberikan informasi mengenai (i) tujuan dan niat mereka, (ii) tindakan mereka dan (iii) kinerja mereka selanjutnya berkaitan dengan masalah-masalah CSR yang berbeda.

Penelitian ini mengacu kepada penelitian yang dilakukan oleh Bouten (Bouten et. Al., 2011), bertujuan memberikan kerangka analisis isi (content analysis) untuk menyelidiki apakah perusahaan melaporkan informasi CSR secara komprehensif. Pelaporan komprehensif, mengharuskan perusahaan untuk mengungkapkan tiga jenis informasi untuk setiap item CSR diungkapkan: (i) visi dan tujuan (VG), (ii) pendekatan manajemen (MA), dan (iii) indikator kinerja (PI). Ketiga jenis informasi didasarkan pada Vuontisjärvi (2006), dan mereka mengacu pada pengungkapan (i) tujuan lain dan nilai-nilai, (ii) tindakan spesifik dan (iii) kinerja aktual dengan cara kuantitatif. Misalnya, untuk 'emisi' item CSR, pendekatan ini berarti bahwa perusahaan mengungkapkan, misalnya, (i) tujuan untuk mengurangi emisi dengan kuantitas tertentu, (ii) tindakan spesifik untuk mewujudkan niat ini dan (iii) pengurangan yang sebenarnya dicapai. Jika sebuah perusahaan melaporkan dengan cara ini, dimungkinkan untuk mendapatkan pandangan lebih jelas tentang penerimaan perusahaan terhadap tanggung jawab sosial dan lingkungan (Adams, 2004). Dengan demikian, laporan yang komprehensif merupakan salah satu syarat yang harus dipenuhi untuk menunjukkan akuntabilitas (Adams, 2004).

Di Indonesia, terdapat UU yang mengatur perseroan dalam menjalankan kegiatan usahanya, yaitu UU No.40 Tahun 2007 pasal 74 yang berisikan: [1] Perseroan yang menjalankan kegiatan usahanya dibidang dan/atau berkaitan dengan sumber daya alam wajib melaksanakan Tanggung Jawab Sosial dan Lingkungan; [2] Tanggung Jawab Sosial dan Lingkungan sebagaimana dimaksud pada ayat (1) merupakan kewajiban perseroan yang dianggarkan dan diperhitungkan sebagai biaya perseroan yang pelaksanaannya dilakukan dengan memperhatikan kepatutan dan kewajarannya; [3] Perseroan yang tidak melaksanakan kewajiban sebagaimana dimaksud pada ayat (1) dikenai sanksi sesuai dengan ketentuan peraturan perundang-undangan; [4] Ketentuan lebih lanjut mengenai Tanggung Jawab Sosial dan Lingkungan diatur dengan peraturan pemerintah.

Pelaksanaan CSR biasanya dicatatkan dalam suatu laporan yang dapat dilaporkan secara terpisah maupun digabung dalam laporan tahunan. Pelaporan CSR di Indonesia diatur oleh IAI (Ikatan Akuntan Indonesia) yang menyarankan kepada perusahaan untuk mengungkapkan tanggungjawab mengenai sosial dan lingkungan sebagaimana tertulis pada Standar Akuntansi Keuangan (PSAK) no 1 (Revisi 2009). Paragraf 12 berbunyi: 
Entitas dapat pula menyajikan, terpisah dari laporan keuangan, laporan mengenai lingkungan hidup dan laporan nilai tambah (value added statement), khususnya bagi industri dimana faktor lingkungan hidup memegang peranan penting dan bagi industri yang menganggap karyawan sebagai kelompok pengguna laporan yang memegang peranan penting. Laporan tambahan tersebut di luar lingkup Standar Akuntansi Keuangan.

Sejarah pertambangan batu bara di Tanjung Enim dimulai sejak zaman kolonial Belanda pada 1919 dengan menggunakan metode penambangan terbuka (open pit mining) di wilayah operasi pertama, yaitu di Tambang Air Laya. Selanjutnya mulai 1923 beroperasi dengan metode penambangan bawah tanah (underground mining) hingga 1940, sedangkan produksi untuk kepentingan komersial dimulai pada 1938. Seiring dengan berakhirnya kekuasaan kolonial Belanda di tanah air, para karyawan Indonesia kemudian berjuang menuntut perubahan status tambang menjadi pertambangan nasional. Pada 1950, Pemerintah RI kemudian mengesahkan pembentukan Perusahaan Negara Tambang Arang Bukit Asam (PN TABA). Pada 1981, PN TABA kemudian berubah status menjadi Perseroan Terbatas dengan nama PT Tambang Batu bara Bukit Asam (Persero), yang selanjutnya disebut Perseroan. Dalam rangka meningkatkan pengembangan industri batu bara di Indonesia, pada 1990 Pemerintah menetapkan penggabungan Perum Tambang Batu bara dengan Perseroan. Sesuai dengan program pengembangan ketahanan energi nasional, pada 1993 Pemerintah menugaskan Perseroan untuk mengembangkan usaha briket batu bara. Pada 23 Desember 2002, Perseroan mencatatkan diri sebagai perusahaan publik di Bursa Efek Indonesia dengan kode "PTBA".

\section{METODE PENELITIAN}

Untuk menilai tingkat pelaporan yang komprehensif, kerangka analisis konten dikembangkan. Analisis isi dapat didefinisikan sebagai metode kodifikasi teks ke kelompok yang berbeda tergantung pada kriteria yang dipilih (Weber, 1990). Metode ini telah sering digunakan untuk memahami dan menggambarkan pola dalam pelaporan CSR (Guthrie \& Abeysekera, 2006).

Seperti diilustrasikan pada Gambar 1 (halaman lampiran), struktur pengkodean terdiri dari dua dimensi: (i) konten dan (ii) jenis informasi. Dimensi pertama terdiri dari dua tingkat: (i) wilayah dan (ii) item. Mula-mula peneliti mengelompokkan informasi pada bidang pengungkapan yang ada, kemudian pada item pengungkapan dan akhirnya pada jenis informasi. Menurut Krippendorff (2004), struktur pengkodean dalam bentuk pohon memiliki keuntungan sebagai berikut: (i) kriteria yang membingungkan dapat diminimalkan, (ii) skema keputusan yang dapat secara drastis mengurangi sejumlah besar alternatif, (iii) skema keputusan yang dapat mencegah ketidakandalan kategori.

Global Reporting Initiative (versi 3.1) dijadikan sebagai titik awal untuk pengembangan struktur pengkodean karena kerangka kerja GRI adalah global, memperoleh penerimaan internasional (Farneti \& Guthrie, 2009), dianggap sebagai kerangka kerja yang ketat untuk aplikasi pelaporan triple bottom line (Lamberton, 2005) dan disusun oleh berbagai ahli setelah berkonsultasi dengan berbagai jenis pemangku kepentingan (Reynolds \& Yuthas, 2008). Selain itu, pedoman GRI sudah tersedia di website GRI. Pedoman ini dimaksudkan untuk semua jenis perusahaan, memungkinkan struktur pengkodean digunakan untuk industri yang berbeda (Willis, 2003). Akhirnya, pedoman GRI memberikan gambaran terstruktur dari isi dasar pelaporan CSR. Isi dasar dibagi menjadi enam wilayah (ekonomi, lingkungan hidup, hak asasi manusia, praktik ketenagakerjaan dan pekerjaan yang layak, tanggung jawab produk, dan masyarakat) dan beberapa item (lihat Gambar 2 halaman lampiran).

Global Reporting Initiative (GRI), yang merupakan panduan pelaporan perusahaan untuk mendukung pembangunan berkelanjutan yang digagas oleh PBB lewat Coalition for Environmental Economies (CERES) dan UNEP pada tahun 1997. GRI merupakan organisasi non-profit yang mempromosikan keberlanjutan sosial, ekonomi dan lingkungan. GRI menyediakan kerangka 
pelaporan keberlanjutan yang komprehensif bagi semua perusahaan dan organisasi yang banyak digunakan diseluruh dunia. Pedoman pengungkapan GRI terdiri dari G3, G3.1 dan G4. G3 atau yang sering dikenal dengan G 3.0 merupakan versi awal dari pedoman GRI yang terdiri dari 79 indikator dan merupakan pedoman yang sering digunakan sampai saat ini. G3.1 merupakan versi pengembangan dari G3 yang di dalamnya terkandung 84 indikator termasuk 79 indikator yang digunakan sebelumya pada G3 dengan beberapa perubahan dan tambahan-tambahan lainnya yang dinilai lebih menyempurnakan pedoman GRI. G4 merupakan pedoman baru yang masih dalam tahap pengembangan dan belum terdapat informasi yang memadai.

GRI menunjukkan bahwa perusahaan harus menyediakan berbagai informasi yang berbeda (strategi dan profil, pendekatan manajemen dan kinerja indikator) ketika mengungkapkan item CSR. Menurut Bouten (Bouten, 2011), dimensi kedua membedakan antara tiga jenis informasi, berdasarkan pada karya Vuontisjärvi (2006).

Visi dan tujuan (VG), sejalan dengan Vuontisjärvi (2006), kategori ini meliputi pengungkapan yang menyediakan informasi tentang tujuan lain atau nilai-nilai. Kategori ini meliputi demikian pengakuan perusahaan terhadap nilai-nilai CSR (misalnya, berjuang untuk pengurangan konsumsi energi. Pendekatan manajemen (MA), mirip dengan Vuontisjärvi (2006), kategori ini mencakup bagaimana perusahaan menangani masalah CSR dengan menggambarkan tindakan atau praktik yang diadopsi. Indikator kinerja (PI), mirip dengan Vuontisjärvi (2006), kategori ini mencerminkan prestasi yang sebenarnya CSR dengan menyediakan ukuran kuantitatif tentang kinerja CSR.

\section{HASIL DAN PEMBAHASAN}

PT Bukit Asam (Persero) Tbk telah merumuskan pola kebijakan jangka panjang dalam pelaksanaan tanggung jawab perusahaan yang terintegrasi dalam bentuk "Pedoman CSR PTBA" yang mencakup enam fokus kegiatan, yaitu bidang: (1) ekonomi, (2) lingkungan, (3) hak azasi manusia, (4) praktik ketenagakerjaan dan kelaikan kerja, (5) tanggung jawab produk, dan (6) kemasyarakatan. Keenam fokus kegiatan tersebut mengacu kepada kaidah internasional mengenai keberhasilan implementasi CSR yang ditetapkan oleh Global Reporting Initiatives (GRI), yang dirumuskan dalam strategi implementasi yang dilandasi oleh etika/norma bisnis yang berlaku, meliputi: pembangunan ekonomi dan pemberdayaan masyarakat secara berkelanjutan untuk meningkatkan kesejahteraan komunitas lokal serta masyarakat secara luas; peduli terhadap pelestarian lingkungan hidup, termasuk restorasi lahan pasca tambang; jaminan pelaksanaan non diskriminasi dan penghargaan hak azasi manusia; penerapan jaminan kesehatan dan keselamatan kerja serta upaya peningkatan kesejahteraan karyawan; penerapan jaminan keamanan penggunaan produk dan kepuasan pelanggan; dan menjalin hubungan harmonis dengan masyarakat yang dilandasi dengan prinsip-prinsip tata kelola yang baik.

Tabel 1 Pengungkapan Area Ekonomi menurut GRI 3.1

\begin{tabular}{clccc}
\hline & \multicolumn{1}{c}{ Content } & \multicolumn{3}{c}{ Information Types } \\
\hline Areas & \multicolumn{1}{c}{ Items } & VG & MA & PI \\
\hline Economic & Direct economic impacts & $\sqrt{ }$ & $\sqrt{ }$ & $\sqrt{ }$ \\
& Market presence & $\sqrt{ }$ & $\sqrt{ }$ & $\sqrt{ }$ \\
& Indirect economic impacts & $X$ & $X$ & $X$ \\
& Compliance & $X$ & $X$ & $X$ \\
\hline
\end{tabular}

Sumber: Hasil pengolahan data 


\section{Direct Economic Impacts}

Pada 2011, produksi batu bara Perseroan berhasil ditingkatkan 3,9\% menjadi sebesar 12,95 juta ton. Volume penjualan batu bara juga naik 4,0\% menjadi 13,47 juta ton. Perseroan mampu memanfaatkan kondisi membaiknya harga jual batu bara di pasar domestik maupun ekspor sehingga mencatat kinerja keuangan yang baik, yaitu mencapai total nilai penjualan meningkat menjadi sebesar Rp10,58 triliun, atau naik 33,8\% dari nilai penjualan 2010, yang sebesar Rp7,91 triliun. Perseroan juga berhasil menjalankan efisiensi operasional sehingga persentase peningkatan beban pokok penjualan maupun beban usaha dapat ditekan di bawah persentase peningkatan penjualan. Perseroan meraih laba bersih sebesar Rp3,09 triliun pada tahun 2011, naik secara signifikan sebesar 53,6\% dibandingkan dengan tahun sebelumnya. Akibatnya, laba bersih per saham juga naik dengan persentase yang sama dari Rp872 pada 2010 menjadi Rp 1.339 pada 2011. Kenaikan laba bersih tersebut terjadi karena adanya peningkatan pendapatan usaha yang lebih tinggi dibandingkan kenaikan harga pokok penjualan dan beban usaha. Kenaikan pendapatan usaha terutama dapat dicapai baik karena meningkatnya harga jual dan maupun volume penjualan batu bara pada periode tersebut dibandingkan dengan pada periode yang sama tahun 2010.

\section{Market Presence}

Kondisi perekonomian Asia Pasifik yang relatif mampu bertahan dari pengaruh negatif perekonomian global dan kejadian banjir besar di Queensland pada penghujung 2010 yang sempat membuat terganggunya pasokan batu bara dari Australia membuat harga rata-rata batu bara di pasar global tahun 2011 meningkat. Hal ini berdampak positif pada perolehan harga jual batu bara Perseroan di pasar ekspor yang meningkat 50,08\% menjadi rata-rata senilai US\$101,04 per ton dibandingkan angka US\$67,01/ton pada 2010. Kondisi pasar batu bara global tersebut membuat rata-rata harga jual batu bara Perseroan di pasar domestik juga meningkat 23,1\% menjadi sebesar Rp.755.220/ton dibandingkan rata-rata sebesar Rp613,342/ ton pada 2010. Peningkatan harga jual rata-rata tersebut membuat profitabilitas Perseroan meningkat, sejalan dengan peningkatan volume penjualan.

Tabel 2 Pengungkapan Area Lingkungan menurut GRI 3.1

\begin{tabular}{cllccc}
\hline & \multicolumn{1}{c}{ Content } & \multicolumn{3}{c}{ Information Types } \\
\hline \multicolumn{1}{c}{ Areas } & \multicolumn{1}{c}{ Items } & VG & MA & PI \\
\hline Environment & Materials & $\sqrt{ }$ & $\sqrt{ }$ & $X$ \\
& Energy & $\sqrt{ }$ & $\sqrt{ }$ & $X$ \\
& Water & $\sqrt{ }$ & $\sqrt{ }$ & $\sqrt{ }$ \\
& Biodiversity & $X$ & $X$ & $X$ \\
& Emissions, effluents and waste & $\sqrt{ }$ & $\sqrt{ }$ & $\sqrt{ }$ \\
& Products and services & $\sqrt{ }$ & $\sqrt{ }$ & $\sqrt{ }$ \\
& Compliance & $\sqrt{ }$ & $\sqrt{ }$ & $\sqrt{ }$ \\
& Transport & $X$ & $X$ & $X$ \\
\hline
\end{tabular}

Sumber: Hasil pengolahan data

Misi Perseroan dalam bidang pengelolaan lingkungan diwujudkan melalui penerapan program-program pengelolaan, pemantauan, pengembangan dan rehabilitasi lingkungan secara berkelanjutan.

\section{Water}

Perseroan melakukan pemantauan secara rutin terhadap kondisi lingkungan di sekitar area penambangan dengan tujuan meminimalkan kerusakan lingkungan yang mungkin terjadi, sekaligus sebagai bagian dari upaya mitigasi risiko lingkungan. Kegiatan pemantauan lingkungan yang 
dilakukan meliputi antara lain pemantauan kualitas air, kualitas udara, yang hidup di sekitar area pertambangan.

\section{Emissions, Effluents, and Waste}

Perseroan menggunakan standar parameter yang telah ditetapkan dalam Peraturan Gubernur Sumatera Selatan No. 15 tanggal 15 Mei 2005 mengenai Baku Mutu Emisi Sumber Tidak Bergerak (STB) untuk mengelola emisi, effluent, dan limbah. Pengelolaan kualitas udara dilakukan melalui di antaranya: pemeliharaan dan penyiraman jalan tambang dengan truk tangki air, penanaman pohon di lokasi buffer zone dan lokasi yang final tambang, dan melakukan penyemprotan debu (dust suppression system) di lokasi stockpile secara reguler dan pemantauan emisi genset serta incenerator.

Selain emisi udara, Perseroan mengelola limbah umum dan limbah bahan berbahaya dan beracun. Adapun langkah pengelolaan selengkapnya adalah sebagai berikut. Limbah umum, yang berasal dari area perumahan dan area penambangan Perseroan, dibuang ke Tempat Pembuangan Akhir (TPA) di Desa Darmo. Untuk limbah yang bersifat organik, pengelolaannya melibatkan masyarakat sekitar, yakni dijadikan pupuk Bokashi yang kemudian dibeli oleh Perseroan untuk digunakan saat revegetasi lahan. Limbah B3, yang berasal dari unit kerja (bengkel), antara lain seperti oli bekas, batere bekas dan filter oli bekas, pengelolaannya dilakukan sesuai PP No. 18 jo No.85 Tahun 1999 tentang pengelolaan limbah B3. Selain melakukan daur ulang limbah B3 bekerjasama dengan mitra yang telah mempunyai izin KLH, Perseroan melakukan pembakaran limbah B3 dengan incenerator dan melaksanaan proses bioremediasi untuk material yang tercemar hydrocarbon.

\section{Products and Services}

Perseroan menjaga kualitas produksi melalui mekanisme quality control yang ketat pada setiap tahapan produksi. Proses pengendalian kualitas ini berpedoman pada standar Sistem Manajemen Mutu ISO 9001: 2008. Dengan sistem tersebut, Perseroan melakukan uji sampling untuk memastikan kualitas batu bara yang akan ditambang. Pengujian kualitas batu bara kemudian dilakukan di areal tambang, stockpile di daerah penambangan sebelum pemuatan ke kereta api atau dikirim ke konsumen, diikuti dengan pengujian di areal stockpile pelabuhan sebelum pemuatan ke kapal. Program SCMS yang telah go-live akhir 2011 lalu dimaksudkan juga untuk mendukung program penjagaan kualitas secara terintegrasi. Analisis kualitas batu bara dilakukan oleh Unit laboratorium Perseroan yang telah menerima sertifikat Sistem Manajemen Mutu Laboratorium ISO/IEC 17025: 2005 dari Komite Akreditasi Nasional (KAN). Laboratorium ini juga bertanggung jawab melakukan pengujian kualitas air buangan tambang untuk menjaga terpenuhinya Standar Baku Mutu Lingkungan.

\section{Compliance}

Perseroan melakukan kegiatan pengelolaan lingkungan secara berkelanjutan untuk mengurangi dampak kegiatan pertambangan terhadap lingkungan dan masyarakat, sesuai dengan salah satu misi perusahaan, yakni "Memberikan kontribusi yang maksimal dalam meningkatkan kesejahteraan masyarakat dan pelestarian lingkungan”. Untuk mengukur efektivitas pengelolaan lingkungan, setiap tahun Perseroan menetapkan parameter indikator sasaran lingkungan sesuai dengan peraturan yang berlaku. Indikator tersebut mengacu ketentuan Pemda setempat (Pergub Sumsel No.17 dan No.18 tahun 2005) mengenai pemenuhan baku mutu lingkungan untuk pemeriksaan beberapa indikator baku mutu lingkungan (BML). Setiap program pelaksanaan pengelolaan lingkungan yang dijalankan kemudian dipantau dan dievaluasi dengan menggunakan parameter yang telah mempertimbangkan penilaian terhadap dampak utama yang muncul akibat kegiatan penambangan. Evaluasi terhadap indikator sasaran lingkungan tersebut kemudian dibahas secara rutin setiap tahun pada forum manajemen lingkungan, sesuai sistem terakreditasi ISO 14001: 2004, sebagai bagian upaya perbaikan terus menerus, sehingga dampak lingkungan dari operasional kegiatan tambang dapat dikendalikan. 
Tabel 3 Pengungkapan Area Hak Asasi Manusia menurut GRI 3.1

\begin{tabular}{clccc}
\hline \multicolumn{1}{c}{ Content } & \multicolumn{2}{c}{ Information Types } \\
\hline \multicolumn{1}{c}{ Areas } & \multicolumn{1}{c}{ Items } & VG & MA & PI \\
\hline Human Rights & Investment and procurement practices & $\sqrt{ }$ & $X$ \\
& Non-discrimination & $\sqrt{ }$ & $\sqrt{ }$ & $X$ \\
& Freedom of association and collective bargaining & $\sqrt{ }$ & $\sqrt{ }$ & $X$ \\
& Child labor & $X$ & $X$ & $X$ \\
& Forced and compulsory labor & $X$ & $X$ & $X$ \\
& Security practices & $X$ & $X$ & $X$ \\
& Indigenous rights & $X$ & $X$ & $X$ \\
& Compliance & $X$ & $X$ & $X$ \\
\hline
\end{tabular}

Sumber: Hasil pengolahan data

Bagi Perseroan, selain menjadi salah satu pemangku kepentingan, karyawan merupakan aset yang menentukan di dalam keberhasilan Perseroan untuk mewujudkan tujuan dan mencapai target usahanya. Perseroan sangat menyadari makna penting dari terciptanya hubungan kerja sama yang serasi antara manajemen dan seluruh karyawan Perseroan. Oleh karenanya dalam setiap kegiatan organisasi, Perseroan menjalankan praktik atau perlakuan yang sama terhadap semua karyawan dengan tidak memandang suku, ras, agama, gender dan haluan politiknya, begitu pula semua karyawan memiliki kebebasan berserikat dan melaksanakan Perjanjian Kerja Bersama.

Tabel 4 Pengungkapan Area Praktik Tenaga Kerja dan Pekerjaan yang Layak menurut GRI 3.1

\begin{tabular}{clccc}
\hline \multicolumn{1}{c}{ Content } & \multicolumn{3}{c}{ Information Types } \\
\hline \multicolumn{1}{c}{ Areas } & \multicolumn{1}{c}{ Items } & VG & MA & PI \\
\hline Labor practices & Employment & $\sqrt{ }$ & $\sqrt{ }$ & $\sqrt{ }$ \\
and decent work & Labor/management relations & $\sqrt{ }$ & $\sqrt{ }$ & $X$ \\
& Occupational health and safety & $\sqrt{ }$ & $\sqrt{ }$ & $\sqrt{ }$ \\
& Training and education & $\sqrt{ }$ & $\sqrt{ }$ & $\sqrt{ }$ \\
& Diversity and equal opportunity & $\sqrt{ }$ & $\sqrt{ }$ & $\sqrt{ }$ \\
& Employee satisfaction & $X$ & $X$ & $X$ \\
& Compliance & $\sqrt{ }$ & $\sqrt{ }$ & $\sqrt{ }$ \\
\hline
\end{tabular}

Sumber: Hasil pengolahan data

\section{Employment}

Perseroan menerapkan kebijakan rekrutmen umum yang menetapkan bahwa proses penerimaan pegawai berawal dari kebutuhan Satuan kerja (user) dan dalam bagian akhir (wawancara) juga melibatkan user. HRD bertindak sebagai fasilitator dan regulator proses penerimaan. Perseroan telah selesai menyusun peta kebutuhan SDM, termasuk kebutuhan fresh graduate maupun reposisi SDM untuk mengisi berbagai posisi jabatan di jenjang organisasi sesuai perkembangan Perusahaan. Pada pelaksanaannya rekrutmen dilaksanakan berdasarkan rencana kebutuhan tenaga kerja jangka panjang (3 tahun ke depan untuk lulusan S-1 dan 1 tahun ke depan untuk lulusan setingkat SMA). Proses seleksi melibatkan pihak ketiga dan dilakukan melalui pemenuhan aspek administrasi, attitude test, psikotes, tes kesehatan, dan wawancara. Sebelum diangkat menjadi pegawai tetap, terlebih dahulu para calon pegawai tersebut mengikuti program management trainee, disebut Graduate Development Program. Sedangkan untuk pengisian jabatan kosong, rekrutmen dilaksanakan dengan melakukan seleksi melalui assessment kompetensi (teknis) untuk jenjang Jabatan IV ke bawah dan menggunakan assessment centre untuk Jenjang Jabatan III ke atas. 


\section{Occupational Health and Safety}

Perseroan telah menerapkan serangkaian kebijakan terkait serta penyediaan sarana dan prasarana bagi setiap karyawan yang memungkinkan dicapainya standar kesehatan dan keselamatan kerja serta lingkungan yang tinggi dalam industrinya. Dalam implementasi K3, Perseroan telah memperoleh sertifikasi Sistem Manajemen K3 (SMK3) dari Depnakertrans RI. Selain Keselamatan Kerja, Perseroan juga memperhatikan kesehatan para pegawai di lingkungan kerjanya maupun di lingkungan keluarganya serta keluarga mereka, seperti diamanatkan peraturan perundangan yang berlaku. Sesuai dengan peraturan UU No. 1 th 1970 dan Kepmen P \& E No. 555.K/26/M.PE/1995 dan untuk menjamin risiko terpaparnya pegawai dari bahaya di lingkungan kerja seperti debu, kebisingan, getaran, iklim kerja, dll yang dapat menimbulkan gangguan kesehatan pegawai maupun PAK/PAHK, maka dilakukan kegiatan antara lain: [1] Pengukuran Parameter Lingkungan kerja; pada 2011 telah dilakukan pengukuran parameter lingiklim kerja sebanyak 40 titik, getaran body sebanyak 40 titik, radiasi sinar UV sebanyak 25 titik, debu personal sebanyak 40 titik, kadar asbes sebanyak 23 titik, kadar kuarsa sebanyak 24 titik, intensitas kebisingan sebanyak 103 titik. [2] Pemeriksaan Kesehatan Pegawai, meliputi: pemeriksaan kesehatan prakarya, dilakukan saat rekruitmen pegawai. Guna menyeleksi pegawai yang mempunyai kesehatan prima, dan dapat ditempatkan sesuai kondisi kesehatannya, serta didapatkan data riwayat kesehatan sebelum bekerja di PTBA; pemeriksaan kesehatan berkala (PKB), dilakukan secara berkala minimal 1 tahun sekali. Guna memelihara dan mempertahankan derajat kesehatan pegawai selama bekerja di PTBA. Pada tahun 2011 PTBA-UPTE telah melakukan PKB sebanyak 1.466 pegawai; dan pemeriksaan kesehatan khusus, dilakukan pada pegawai: yang menjalani rotasi ke lingkungan kerja dengan beban risiko lebih tinggi, baru sembuh sakit yang lama dan menjelang masa pensiun; promosi kesehatan pegawai, dengan melakukan peningkatan kesadaran akan kesehatan kerja pegawai, yaitu: memberikan pendidikan, pelatihan, konseling, penyuluhan untuk mencegah gangguan kesehatan pegawai maupun PAK/PAHK serta penyakit umum; pemantauan higienitas dan sanitasi jasa boga pegawai serta layanan kesehatan preventif lainnya.

\section{Training and Education}

Misi pengelolaan Sumber Daya Manusia (SDM) adalah "Menyediakan SDM dan Sistem Manajemen SDM yang terbaik, untuk menunjang pengembangan Perusahaan”. Sementara Visi Perusahaan dalam pengelolaan SDM adalah "Menjadikan SDM PT Bukit Asam (Persero), Tbk sebagai keunggulan kompetitif Perusahaan”. Untuk mewujudkan misi dan visi tersebut, Perseroan menetapkan serangkaian langkah strategis pengelolaan SDM yang implementasinya dilaksanakan dalam beberapa tahap. Rencana strategis tersebut ditujukan untuk memenuhi kebutuhan SDM yang unggul dan mengembangkan kompetensi SDM yang telah ada maupun yang akan direkrut guna menunjang pengembangan perusahaan menjadi "world class company". Dalam jangka pendek, Perseroan akan menempuh beberapa langkah, mencakup: tugas belajar ke luar negeri untuk karyawan berprestasi dan berpotensi; rekrutmen tenaga siap pakai yang berkualitas untuk mendukung peningkatan produksi dan bidang usaha baru, seperti PLTU, infrastruktur dan CBM; menyiapkan succession planning dengan dukungan teknologi informasi; melakukan penyelarasan (alignment) organisasi dan penyempurnaan sistem manajemen SDM; memfasilitasi pembentukan budaya unggul.

Sementara untuk jangka menengah beberapa langkah lanjutan yang dipersiapkan meliputi: implementasi succession plan bagi SDM eksisting yang berkompeten; penerapan carrier path dan remuneration package dengan dukungan balanced scorecard tools dengan dukungan penuh teknologi informasi yang didesain khusus untuk pengelolaan SDM; penerapan sistem pelatihan yang mengintegrasikan peningkatan kompetensi dengan pemahaman budaya unggul yang menjunjung tinggi nilai-nilai perusahaan. 


\section{Diversity and Equal Opportunity}

Perseroan terus mengembangkan dan menyempurnakan seluruh pranata yang mendukung penilaian kemampuan pegawai secara adil, fair, dan transparan. Hal ini dilakukan untuk menjamin persamaan kesempatan bagi seluruh pegawai dalam mengembangkan karier mereka sesuai dengan perkembangan perusahaan. Perseroan menerapkan sistem tools "Balanced Scorecard" untuk mendapatkan akurasi, kesamaan, dan transparansi yang berimbang dalam menilai kompetensi seluruh pegawai, perkembangan karier, tanggung jawab dan remunerasinya. Perseroan kemudian memberikan kesempatan kepada seluruh pegawai untuk memperjuangkan hak-haknya secara berimbang dan setara melalui Serikat Pekerja Bukit Asam (SPBA). Kesepakatan yang setara antara kewajiban maupun hak pegawai di satu pihak (baik secara pribadi maupun melalui SPBA) dengan Perseroan dilain pihak kemudian dituangkan dalam perjanjian kerja bersama (PKB). Melalui PKB ini pola hubungan industrial antara Perseroan dan dukungan pegawai terhadap keberlangsungan operasional yang kondusif lebih terjamin. Pengembangan karier dilakukan melalui rotasi/promosi berbasis kompetensi dan kinerja pegawai sesuai kebutuhan perusahaan. Sepanjang tahun 2011 lalu, Perseroan telah melakukan promosi terhadap 157 orang pegawai.

\section{Compliance}

Perseroan telah menetapkan kebijakan mendasar mengenai Keselamatan dan Kesehatan Kerja, yakni "Keselamatan dan Kesehatan Kerja adalah tanggung jawab semua pihak, oleh sebab itu Perseroan bersama pihak terkait bertekad menciptakan lingkungan kerja yang sehat, bebas cidera dan melakukan kegiatan operasional sesuai kaidah yang berlaku". Untuk mendapatkan standar Keselamatan dan Kesehatan Kerja yang maksimum, Perseroan sejak 2007 menerapkan perluasan Standar Manajemen K3 (SMK3) dari Departemen Tenaga Kerja dan Transmigrasi RI dan pada tahun 2008 juga menerapkan sistem standar K3 dari OHSAS 18001:2007. Sejak Juli 2010, Perseroan telah mengintegrasikan semua sistem operasional ini kedalam Bukit Asam Management System (BAMS).

Tabel 5 Pengungkapan Area Tanggung Jawab Produk menurut GRI 3.1

\begin{tabular}{llccc}
\hline \multicolumn{1}{c}{ Content } & \multicolumn{3}{c}{ Information Types } \\
\hline \multicolumn{1}{c}{ Areas } & \multicolumn{1}{c}{ Items } & VG & MA & PI \\
\hline Product & Customer health and safety & $X$ & $X$ & $X$ \\
responsibility & Product and service labeling & $\sqrt{ }$ & $\sqrt{ }$ & $X$ \\
& Marketing communications & $\sqrt{ }$ & $\sqrt{ }$ & $\sqrt{ }$ \\
& Customer privacy & $X$ & $X$ & $X$ \\
& Compliance & $\sqrt{ }$ & $\sqrt{ }$ & $\sqrt{ }$ \\
& Customer satisfaction & $\sqrt{ }$ & $\sqrt{ }$ & $X$ \\
\hline
\end{tabular}

Sumber: Hasil pengolahan data

Perseroan menyadari makna penting dan manfaat dari pemenuhan standar kualitas serta perlindungan konsumen terhadap setiap produk yang dihasilkan, mengingat keduanya mempunyai pengaruh yang signifikan bagi pertumbuhan kinerja usaha secara berkelanjutan. Perseroan menetapkan dan memberlakukan kriteria yang ketat dalam proses dan output produksi maupun pengawasan kualitas setiap produknya.

\section{Product and Service Labeling}

Komitmen jaminan kualitas produk; jaminan kualitas ini sangat penting karena selain memengaruhi kelancaran operasional bisnis konsumen juga merupakan faktor penentu tingkat kepercayaan konsumen agar terus menggunakan batu bara hasil produksi Perseroan. Oleh karena itu, 
Perseroan selalu memberikan jaminan bahwa kualitas batu bara yang diterima konsumen telah sesuai dengan kesepakatan kontrak terkait. Jaminan kualitas dikontrol melalui penerapan manajemen mutu yang melibatkan pelaksanaan proses analisis terakreditasi.

\section{Marketing Communications}

Pelayanan pelanggan; Perseroan selalu mengutamakan prinsip transparansi dan responsibilitas dalam memberikan layanan kepada konsumen demi memenuhi komitmen layanan terbaik kepada konsumen. Perseroan memberikan tanggapan yang cepat terhadap berbagai permintaan dan keluhan konsumen sebagai bagian dari komitmen pelayanan Perseroan. Perseroan meyakini penerapan komitmen pelayanan terbaik akan mampu mendukung target peningkatan penjualan Perseroan di masa mendatang. Untuk menjamin pelayanan pada pelanggan, Perseroan membuka layanan pengaduan dengan menyediakan saluran telepon, email, maupun surat kepada pelanggan. Selama 2011, Perseroan menerima dua kali pengaduan dari pelanggan. Perseroan telah menindaklanjuti keluhan pelanggan tersebut, sehingga permasalahan dengan konsumen dimaksud telah diselesaikan.

\section{Compliance}

Implementasi Supply Chain Management System; Perseroan mulai menerapkan Suply Chain Management System (SCMS) secara penuh sejak penambangan hingga aspek keuangan, yakni status tagihan dan inventori di stockpile pelanggan utama. Penerapan SCMS akan membuat koordinasi pengambilan keputusan semakin cepat, karena didukung oleh data akurat, real-time dan reliable sehingga Perseroan akan mampu memenuhi komitmen kepada pembeli dengan kualitas dan kuantitas yang sesuai.

Tabel 6 Pengungkapan Area Masyarakat menurut GRI 3.1

\begin{tabular}{clccc}
\hline & Content & \multicolumn{3}{c}{ Information Types } \\
\hline \multicolumn{1}{c}{ Areas } & \multicolumn{1}{c}{ Items } & VG & MA & PI \\
\hline Society & Community & $\sqrt{ }$ & $\sqrt{ }$ & $\sqrt{ }$ \\
& Corruption & $\sqrt{ }$ & $\sqrt{ }$ & $X$ \\
& Public policy & $\sqrt{ }$ & $\sqrt{ }$ & $X$ \\
& Anti-competitive behavior & $X$ & $X$ & $X$ \\
& Compliance & $\sqrt{ }$ & $\sqrt{ }$ & $\sqrt{ }$ \\
\hline
\end{tabular}

Sumber: Hasil pengolahan data

Perseroan telah merumuskan program Tanggung Jawab Jawab Sosial Perusahaan dalam sebuah pola yang terpadu, untuk mewujudkan visi memberikan nilai optimal bagi para pemangku kepentingan Perseroan termasuk masyarakat. Melalui Program Kemitraan dan Bina Lingkungan (PKBL), serta Program Bina Wilayah, Perseroan secara sistematis telah melaksanakan serangkaian kegiatan dengan melibatkan masyarakat, baik dalam tahap perencanaan maupun pelaksanaan programprogram yang terkait. Sesuai dengan prinsip transparansi, Perseroan juga membuka akses dan menjalin komunikasi timbal balik dengan masyarakat dan pihak-pihak yang terkait.

\section{Community}

Program Bina Lingkungan PTBA dielaborasi dalam enam fokus kegiatan, yaitu Program Pendidikan, Program Pengembangan Prasarana dan Sarana umum, Program Perbaikan Sarana Ibadah, Program Peningkatan Kesehatan, Program Pelestarian Alam dan Program Bantuan Bencana. Tujuan yang hendak diraih adalah peningkatan standar hidup dan kesejahteraan masyarakat. Seiring dengan peningkatan kegiatan Bina Lingkungan Perseroan, total dana yang disalurkan melalui pelaksanaan 
Program Bina Lingkungan, mengalami peningkatan sebesar 76,9\% dari Rp25,7 miliar di tahun 2010 menjadi Rp45,3 miliar di tahun 2011, termasuk partisipasi dalam Program BUMN Peduli, sebesar Rp3,0 miliar. Semua bantuan dalam rangka pelaksanaan program Bina Lingkungan disalurkan melalui empat wilayah kerja mencakup Unit pertambangan Tanjung Enim, Unit Pertambangan Ombilin, Pelabuhan Tarahan dan Dermaga Kertapati.

\section{Corruption}

Perseroan mengoptimalkan peranan Manajemen Risiko untuk melakukan identifikasi dan mitigasi atas berbagai risiko yang dihadapi dan berpotensi menghambat pencapaian target Perseroan. Hasil identifikasi kemudian dimitigasi dan ditindaklanjuti dengan langkah-langkah antisipatif terhadap berbagai perkembangan kondisi lingkungan usaha yang bisa berdampak negatif. Proses Manajemen Risiko Perseroan merupakan suatu proses terstruktur, sistematis serta berulang untuk meningkatkan kinerja pengelolaan risiko perusahaan yang berkelanjutan (continuous improvement). Proses ini mengacu pada standar AS/NZ 4360: 2004 yang tercantum dalam pedoman manajemen risiko korporat terintegrasi PTBA. Risiko Operasional, yaitu risiko yang disebabkan oleh ketidakcukupan dan atau tidak berfungsinya proses internal, kesalahan manusia dan kegagalan sistem. Risiko yang masuk ke kelompok ini antara lain risiko mutu batu bara, risiko SDM, risiko pompa, risiko kontraktor, risiko dokumen, risiko fraud and corruption, dan lain-lain.

\section{Compliance}

Pelaksanaan PKBL tersebut berpedoman pada Peraturan Menteri Negara Badan Usaha Milik Negara (BUMN) RI No. PER-05/ MBU/2007 tentang Program Kemitraan BUMN dengan Usaha Kecil dan Program Bina Lingkungan sesuai Surat Edaran No. SE-07/MBU/2008 tentang pelaksanaan PKBL. Sedangkan program bina wilayah merupakan perwujuan Penerapan Pasal 74 Undang- Undang No.40 Tahun 2007 tentang Perseroan Terbatas.

\section{SIMPULAN}

Berdasarkan pembahasan tentang pelaporan corporate social responsibility GRI 3.1 dari PT Bukit Asam (Persero) Tbk, didapatkan hasil sebagai berikut. Dari keenam area yang tercakup dalam GRI 3.1 yaitu Economic, Environment, Human Rights, Labor Practices, Product Responsibility, dan Society, area Human Rights adalah area yang memiliki item terbanyak yang sama sekali tidak diungkapkan dalam laporan tahunan yaitu Child labor, Forced and compulsory labor, Security practices, Indigenous rights, dan Compliance. Sedangkan area Labor Practices merupakan area dengan pengungkapan terbaik dengan hanya satu item yang sama sekali tidak diungkapkan dalam laporan tahunan yaitu item Employee satisfaction.

Dari berbagai evaluasi dalam perencanaan dan pelaporan PT Bukit Asam (Persero) Tbk dapat disimpulkan bahwa PT Bukit Asam (Persero) Tbk adalah perusahaan yang cukup mempertimbangkan corporate social responsibility secara optimal. 


\section{DAFTAR PUSTAKA}

Adams, C. A. (2004). The ethical, social and environmental reporting-performance portrayal gap. Accounting, Auditing \& Accountability Journal, 17(5), 731-757.

Archel, P., Fernández, M., \& Larrinaga, C. (2008). The organizational and operational boundaries of triple bottom line reporting: A survey. Environmental Management, 41(1), 106-117.

Bouten, L., Everaert, P., van Liedekerke, Luc., de Moor, L., Christiaens, J. (2011). Corporate social responsibility reporting: A comprehensive picture?. Accounting Forum 35 (2011) 187 - 204.

Farneti, F., \& Guthrie, J. (2009). Sustainability reporting by Australian public sector organisations: Why they report. Accounting Forum, 33(2), 89-98.

GRI. N.d. www.globalreporting.co.id. Diakses tanggal 5 Januari 2013.

Guthrie, J., \& Abeysekera, I. (2006). Content analysis of social, environmental reporting: What is new? Journal of Human Resource Costing and Accounting, 10(2), 114-126.

Hopwood, A. G. (2009). Accounting and the environment. Accounting, Organizations and Society, 34(3-4), 433-439.

Krippendorff, K. (2004). Content analysis: An introduction to its methodology. Thousand Oaks, California: Sage Publications.

Lamberton, G. (2005). Sustainability accounting-A brief history and conceptual framework. Accounting Forum, 29(1), 7-26.

Milne, M., \& Gray, R. (2007). Future prospects for corporate sustainability reporting. In J. Unerman, J. Bebbington, \& B. O’Dwyer (Eds.), Sustainability accounting and accountability (pp. 184207). London: Routledge.

Reynolds, M. A., \& Yuthas, K. (2008). Moral discourse and corporate social responsibility reporting. Journal of Business Ethics, 78(1-2), 47-64.

Undang-Undang Republik Indonesia Nomor 40 Tahun 2007 tentang Perseroan Terbatas.

Unerman, J. (2000). Methodological issues: Reflections on quantification in corporate social reporting content analysis. Accounting, Auditing \& Accountability Journal, 13(5), 667-680.

van Staden, C. J., \& Hooks, J. (2007). A comprehensive comparison of corporate environmental reporting and responsiveness. British Accounting Review, 39(3), 197-210.

Vuontisjärvi, T. (2006). Corporate social reporting in the European context and human resource disclosures: An analysis of Finnish companies. Journal of Business Ethics, 69(4), 331-354.

Weber, R. P. (1990). Basic content analysis (2nd ed.). Sage University Paper Series on Quantitative Applications in the Social Sciences, Series No. 49, Newbury Park, CA: Sage.

Willis, A. (2003). The role of the Global Reporting Initiative's sustainability reporting guidelines in the social screening of investments. Journal of Business Ethics, 43(3), 233-237. 


\section{LAMPIRAN}

Dimension 1: Content

Dimension 2: Information Types

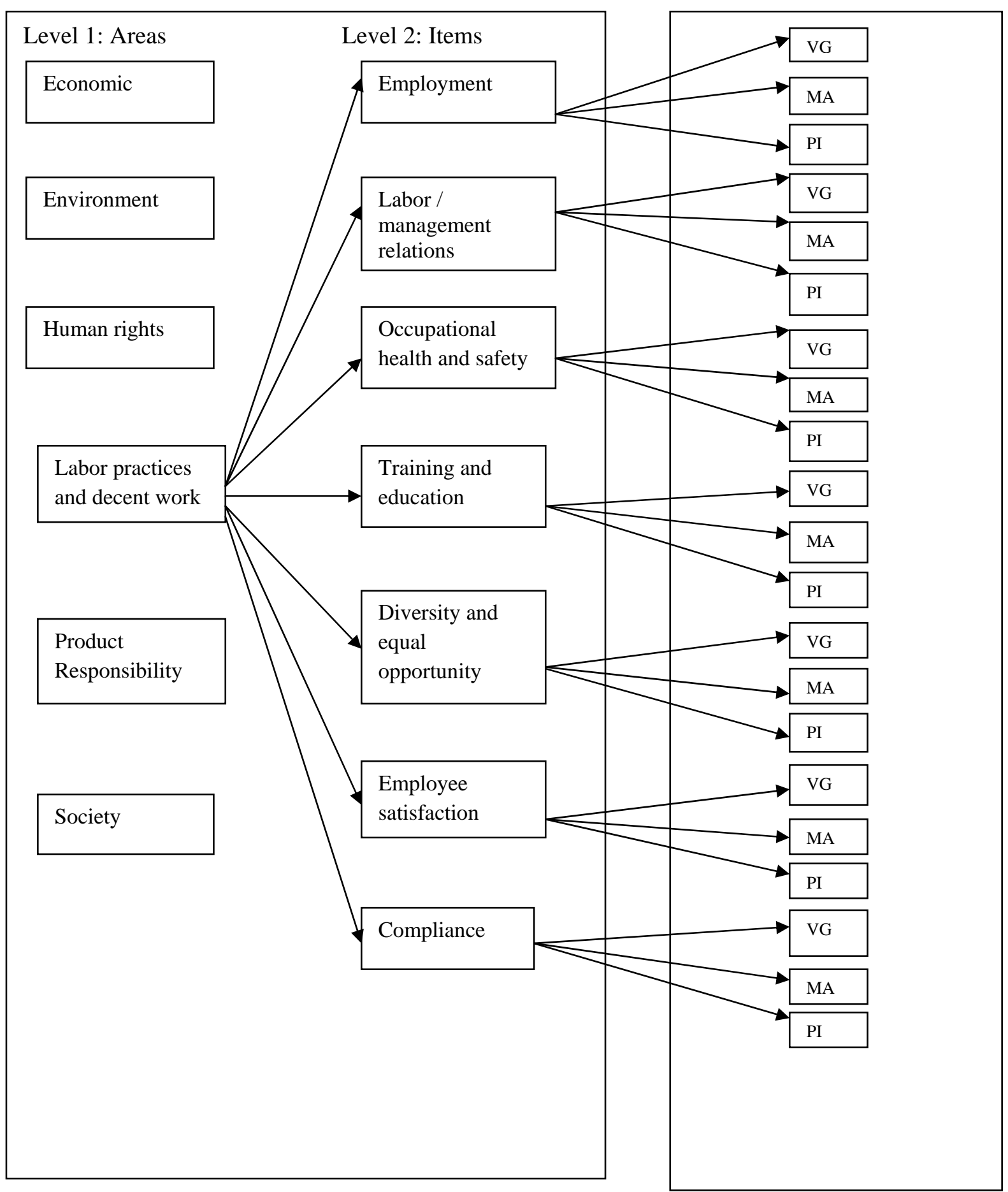




\begin{tabular}{|c|c|}
\hline Areas & Items \\
\hline \multirow{2}{*}{ Economic } & $\begin{array}{ll}\text { - } & \text { Direct economic impacts } \\
\text { - } & \text { Market presence }\end{array}$ \\
\hline & $\begin{array}{l}\text { - Indirect economic impact } \\
\text { - Compliance }\end{array}$ \\
\hline
\end{tabular}

\begin{tabular}{|c|c|}
\hline Environment & $\begin{array}{ll}\text { - } & \text { Materials } \\
\text { - } & \text { Energy } \\
\text { - } & \text { Water } \\
\text { - } & \text { Biodiversity } \\
\text { - } & \text { Emissions, effluents and waste } \\
\text { - } & \text { Products and services } \\
\text { - } & \text { Compliance } \\
\text { - } & \text { Transport } \\
\text { - } & \text { Overall } \\
\end{array}$ \\
\hline
\end{tabular}

\begin{tabular}{|c|c|}
\hline \multirow{2}{*}{ Human rights } & $\begin{array}{ll}\text { - } & \text { Investment and procurement practices } \\
\text { - } & \text { Non-discrimination } \\
\text { - } & \text { Freedom of association and collective bargaining } \\
\text { - } & \text { Child labor }\end{array}$ \\
\hline & $\begin{array}{l}\text { - } \quad \text { Forced and compulsory labor } \\
\text { - Security practices } \\
\text { - Indigenous rights } \\
\text { - } \quad \text { Compliance } \\
\end{array}$ \\
\hline
\end{tabular}

\begin{tabular}{|c|c|}
\hline $\begin{array}{c}\text { Labor practices and decent } \\
\text { work }\end{array}$ & $\begin{array}{ll}\text { - } & \text { Employment } \\
\text { - } & \text { Labor / management relations } \\
\text { - } & \text { Occupational health and safety } \\
\text { - } & \text { Draining and education } \\
\text { - } & \text { Employee satisfaction } \\
\text { - } & \text { Compliance } \\
\end{array}$ \\
\hline
\end{tabular}

\begin{tabular}{|c|c|}
\hline Product responsibility & $\begin{array}{ll}\text { - } & \text { Customer health and safety } \\
\text { - } & \text { Product and service labeling } \\
\text { - } & \text { Marketing communications } \\
\text { - } & \text { Customer privacy } \\
\text { - } & \text { Compliance } \\
\text { - } & \text { Customer satisfaction } \\
\end{array}$ \\
\hline
\end{tabular}

\begin{tabular}{|l|l|l|}
\hline \multirow{2}{*}{ Society } & $\bullet$ Community \\
& $\bullet$ Corruption \\
& $\bullet$ Public policy \\
& $\bullet$ Anti-competitive behavior \\
& $\bullet$ Compliance \\
\hline
\end{tabular}

Gambar 2 The GRI as Reference for the Dimension Content 